\title{
ДИСКУССИИ
}

DOI: https://doi.org/10.15688/jvolsu2.2020.5.14

UDC 81'37

Submitted: 20.12.2019

LBC 81.003

Accepted: 25.05 .2020

\section{IMAGE OF THE HUMAN WORLD AND SEMANTIC ORGANIZATION OF LEXICON IN INTERDISCIPLINARY LINGUISTICS}

\author{
Irina V. Shaposhnikova \\ Institute of Philology of Siberian Branch of Russian Academy of Sciences, Novosibirsk, Russia
}

\begin{abstract}
The article deals with the issues related to the development of principles and methods of semantic organization of lexicon in order to create linguistic resources of various types: dictionaries, databases, corpora, etc. Different techniques of semantic organization of lexicon are viewed as methodological bases for interdisciplinary approaches to investigation of the human image of the world. The issues are studied with reference to different approaches that concern fundamental contradictions between the language and conceptual models of representing the world. Using the reverse dictionary of the associative-verbal database SIBAS, the author conducts a statistical macro-level analysis to stratify the verbal units (the nodes of the SIBAS associative-verbal network) according to the intensity and extension of their incoming links. Thus identified at different levels of stability, SIBAS associativeverbal dominants are matched with the frequency ratings of the relevant lexical items in the textual basis of the Russian National Corpus; they are also matched with the associative dimensions of the Russian language personality, which were discovered earlier on the model of the Russian associative-verbal network in the epoch of perestroika. The author analyzes the part-of speech statistics of the associative dominants, their correlations with the ontogenetically basic concepts, as well as with the glottochronologically basic lexical meanings. Against this background, the author assesses the methodological significance and heuristic potential of the techniques of analysis on the experimentally obtained Russian associative-verbal network, where the conceptual and linguistic models of the world are balanced naturally as a spontaneous (instinctive) manifestation of the intentionality of the Russian language personality.

Key words: language model of the world, conceptual model of the world, semantic organization of lexicon, associative dominants, lexeme, meanings of the lexeme, image of the world: methods of interdisciplinary research.

Citation. Shaposhnikova I.V. Image of the Human World and Semantic Organization of Lexicon in Interdisciplinary Linguistics. Vestnik Volgogradskogo gosudarstvennogo universiteta. Seriya 2. Yazykoznanie [Science Journal of Volgograd State University. Linguistics], 2020, vol. 19, no. 5, pp. 155-172. (in Russian). DOI: https://doi.org/10.15688/jvolsu2.2020.5.14
\end{abstract}

ОБРАЗ МИРА ЧЕЛОВЕКА И СЕМАНТИЧЕСКОЕ УПОРЯДОЧЕНИЕ ЛЕКСИКИ В МЕЖДИСЦИПЛИНАРНОЙ ЛИНГВИСТИКЕ

\author{
Ирина Владимировна Шапошникова \\ Институт филологии Сибирского отделения РАН, г. Новосибирск, Россия
}

Аннотация. Статья затрагивает вопросы разработки принципов и методов семантического упорядочения лексики в целях создания лингвистических ресурсов разного типа: словарей, баз данных, корпусов и пр. 
Способы упорядочения лексики рассматриваются в качестве методологической основы для различных междисциплинарных подходов к исследованию образа мира человека. Дается оценка комплементарности разных подходов в контексте фундаментальных противоречий в соотношении языковой и концептуальной моделей мира. Опираясь на экспериментально полученную базу данных обратного словаря СИБАС, автор проводит стратификацию вербальных единиц, представляющих собой узлы ассоциативно-вербальной сети, на основе статистики интенсивности и разветвленности входящих связей. Выявленные таким образом разнопорядковые ассоциативные доминанты СИБАС сопоставляются с рейтингом соответствующих лексических единиц в частотном словаре НКРЯ и с параметрами русской языковой личности, которые были получены ранее на модели русской ассоциативно-вербальной сети в годы перестройки; анализируется частеречный состав ассоциативных доминант, их связи с развитием онтогенетически базисных концептов, а также лексикой, базисной в глоттохронологическом аспекте. На этом фоне дается оценка методологической значимости и эвристическому потенциалу приемов статистического упорядочения и системного описания лексики на экспериментально полученной модели ассоциативно-вербальной сети, в которой концептуальная и языковая модели мира сбалансированы естественным путем на основе интенциональности русской языковой личности.

Ключевые слова: языковая модель мира, концептуальная модель мира, семантическое упорядочение лексики, ассоциативная доминанта, лексема, значения лексемы, методы исследования образа мира.

Цитирование. Шапошникова И. В. Образ мира человека и семантическое упорядочение лексики в междисциплинарной лингвистике // Вестник Волгоградского государственного университета. Серия 2, Языкознание. - 2020. - Т. 19, № 5. - C. 155-172. - DOI: https://doi.org/10.15688/jvolsu2.2020.5.14

\section{Введение}

Одним из условий успешного междисциплинарного сотрудничества является выработка общей понятийно-категориальной и терминологической базы. К числу значимых для разных наук о человеке понятий можно отнести «образ мира». Это понятие связывают с сознанием человека. Как видоспецифичная организация психических процессов, сознание познается на фоне разных стадий и уровней развития психики у живых организмов нашей планеты.

Психика человека не только активна по отношению к природе, но и характеризуется направленностью, ведущей к упорядоченности психических образов по степени их значимости для человека, саморегуляцией через построение образа себя на фоне других членов общества, трудовой и сопровождающей ее социокоммуникативной деятельностью, включая ее высшую форму - речевую, которая позволяет человеку оперировать специфическими орудиями воздействия на сознание себе подобных - телами языковых знаков. В онтогенезе у человека говорящего благодаря взаимодействию двух сигнальных систем формируется когнитивная и речевая способности при условии включенности в социокоммуникативную среду человеческого общества. Этот инструмент наполняет содержани- ем образ мира, опосредующий жизнедеятельность человека, позволяющий ему ориентироваться в окружающей среде и регулировать свое поведение и поведение других членов общества. Образ мира представляет собой сложное динамическое смысловое образование, которое отражает интенциональность сознания, его социокультурную детерминированность, другоцентричность и оценочность на основе когнитивной и коммуникативно-дискурсивной мыслительной деятельности, упорядочивающей смысловые единицы сообразно их значимости для субъекта.

Как смысловая структура образ мира может изучаться лингвистикой в аспекте развития его содержания, подвижности, устойчивости, направленности (интенциональности, детерминированности), этнокультурной и личностной специфики. В нем можно выделить культурно-историческую и психически актуальную составляющие. Для изучения образа мира в концептуальном и вербальном воплощениях исследователи создают модели его смысловой структуры. При их построении используются термины кониептуальная модель мира (далее - КММ) и языковая модель мира (далее - ЯММ) (см. например: [Караулов, 2010, с. 246; с. 267-274]). Часть КММ, отражающая научно значимые закономерности и связи, строится с применением специальной научной методики на логической 
основе и помогает ориентироваться в решении научных задач. Поэтому понятие КММ носит более общий характер и несводимо к научной картине мира. КММ более упорядочена и отличается бо́льшим единством у разных индивидов и народов по отношению к их ЯММ, которая формируется на основе концептуальной и наследует многие свойственные коммуникативно-когнитивной деятельности человека признаки, обладая своей спецификой. В целом мы будем исходить из представления о несводимости КММ к ЯММ, поскольку обратное противоречило бы имеющимся у современной науки знаниям об эволюции человека. Для овнешнения бесконечно модифицирующегося содержания КММ человек оперирует конечным набором языковых знаков, сложно организованных в способную к гибкой модификации систему. В какой мере и как именно определяются и разрешаются возникающие при этом противоречия между КММ и ЯММ в разных отраслях лингвистики? Одним из инструментов научного исследования этой проблемы является семантическое упорядочение лексики естественного языка. В разных лингвистических отраслях оно выполняется поразному, имеет разные методологическую значимость и эвристический потенциал.

\section{Ассоциативно-вербальная сеть и упорядочение лексики в актуальной диахронии}

Обратимся к результатам статистического упорядочения всего массива вербальных единиц экспериментально полученной ассоциативно-вербальной сети (далее - АВС) по данным обратного словаря СИБАС. Анализ проводился по следующему алгоритму: 1) выявление ассоциативных доминант (опорных узлов сети) по интенсивности (частоте актуализации) связей; экстенсивности (разветвленности) связей (см. табл. 1); 2) выявление текстозависимых частотных показателей ассоциативных доминант по данным частотного словаря НКРЯ (см. табл. 2); 3) соотнесение ассоциативных доминант с базисной лексикой в аспекте онтогенеза, глоттогенеза и культурогенеза (см. табл. 1); 4) выявление опорных узлов параметризации русской языковой личности в АВС (см. табл. 3).
В отечественной ассоциативной лексикографии сложилась практика упорядочения лексики на модели $\mathrm{ABC}$ в целях параметризации образа мира русской языковой личности для дальнейшего выявления его национальнокультурной специфики в ходе межъязыковых сопоставлений. Упорядоченная таким образом лексика получила название в прецедентных, с точки зрения применяемой методики, работах А.А. Залевской «ядро лексикона человека» [Залевская, 2005, с. 109-112]. Такое ядро было получено ею сначала на материале английского языка, факт наличия ядер-коррелятов у других языков подтвержден при межъязыковых сопоставлениях. Ядро определялось на основе обратного ассоциативного словаря, дающего возможность статистической обработки входящих связей (реакция $\leftarrow$ стимул), в отличие от прямого словаря, где представлены исходящие связи (стимул $\rightarrow$ реакция). Эта методика использована для составления сначала английского, а впоследствии и русского ассоциативного тезауруса на основе трехэтапных массовых экспериментов. Установленная таким способом сетевая организация лексикона описывалась А.А. Залевской как «гетерархия», то есть система иерархий, вершины которых представлены единицами ядра лексикона [Залевская, 2005, с. 112], и подвергалась рассмотрению с разных точек зрения: в частности, был проведен частеречный анализ с учетом специфики ассоциативно доминирующих значений и с отсылкой к данным разных наук о фило- и онтогенезе речевой способности у человека. Выяснилось, что в составе ядра лексикона абсолютно доминируют имена существительные - примерно 60-70 \% в разных сопоставляемых языках [Залевская, 2005, c. 111]; cp. с нашими данными по частеречному составу ассоциативных доминант СИБАС, приведенными в столбце 2 таблицы 1. Результаты анализа ядра в частеречном аспекте обнаруживают проблему роли предметных значений в формирования ядра лексикона в фило(онто)генетическом плане. После создания в 90-е гг. $\mathrm{XX}$ в. русского ассоциативного тезауруса (далее - РАС) стало возможным полномасштабное выявление ядра лексикона русских. Ядро РАС представляет собой модель топосов образа мира русской 
языковой личности, в работах авторов проекта оно получило название «ядро языкового сознания русских» (об истории развития проекта см.: [Уфимцева, 2017]). Лейтмотивом работ Н.В. У фимцевой, посвященных иссле- дованию ядра языкового сознания русских, можно считать подход к слову как инструменту культуры, а ядру лексикона как ключу к пониманию системности культуры в процессе ее становления.

\section{Таблица 1. Макроструктура АВС СИБАС (статистически упорядоченная по уровням устойчивости входящих связей модель) ${ }^{1}$}

Table 1. Macro-level structure of the SIBAS associative-verbal network (the levels are statistically ranked according to stability of incoming links)

\begin{tabular}{|c|c|c|c|c|}
\hline \multirow{3}{*}{ У ровень } & \multicolumn{4}{|c|}{ Структура АВС } \\
\hline & \multicolumn{2}{|c|}{$\begin{array}{c}\text { по количеству реакций } \\
\text { (интенсивность соответствующих вербальных узлов) }\end{array}$} & \multicolumn{2}{|c|}{$\begin{array}{c}\text { по кол ичеству стимулов } \\
\text { (экстенсивность вербальных связей) }\end{array}$} \\
\hline & $\begin{array}{c}\text { Диапа- } \\
\text { зон }\end{array}$ & Единицы & $\begin{array}{c}\text { Диапа- } \\
\text { зон }\end{array}$ & Единицы \\
\hline Первый & $\begin{array}{c}11000- \\
2000\end{array}$ & 4 слова: человек, деньги, дом, друг & $\begin{array}{c}600- \\
200 \\
\end{array}$ & $\begin{array}{l}10 \text { слов: человек, жизнь, дом, деньги, } \\
\text { хорошо, плохо, друг, нет, мир, } \boldsymbol{я}\end{array}$ \\
\hline Второй & $\begin{array}{c}1999- \\
1500\end{array}$ & 3 слова: день, мир, домой & $\begin{array}{c}199- \\
150\end{array}$ & $\begin{array}{l}14 \text { слов: время, работа, любовь, сила, } \\
\text { радость, мужчина, смерть, есть, зло, } \\
\text { ребёнок, день, много, человека, город }\end{array}$ \\
\hline Третий & $\begin{array}{c}1499- \\
1000\end{array}$ & $\begin{array}{l}10 \text { слов: жизнь, плохо, время, хорошо, } \\
\text { язык, большой, любовь, вода, дело, } \\
\text { вопрос }\end{array}$ & $\begin{array}{c}149- \\
100\end{array}$ & $\begin{array}{l}58 \text { слов: счастье, большой, хороший, } \\
\text { люди, дело, всегда, ум, предмет, страх, } \\
\text { жизни, путь, боль, машина, взгляд, ум- } \\
\text { ный, парень, разговор, характер, отдых, } \\
\text { учеба, свет, быстро, ответ, враг, успех, } \\
\text { жить, все, лес, труд, дорога, дурак, до- } \\
\text { ма, вода, мой, стол, мужик, фильм, де- } \\
\text { вушка, плохой, урок, вешь, помощь, } \\
\text { ужас, вопрос, сон, долго, красивый, сво- } \\
\text { бода, долг, власть, красота, большая, } \\
\text { людей, Россия, народ, мальчик, ложь, да }\end{array}$ \\
\hline $\begin{array}{l}\text { Четв ер- } \\
\text { тый }\end{array}$ & $\begin{array}{c}999- \\
750\end{array}$ & $\begin{array}{l}19 \text { слов: ложь, ребенок, еда, }, \text { отдых, } \\
\text { город, работа, жизни, боль, зло, Рос- } \\
\text { сия, мужччина, свет, дверь, характер, } \\
\text { машина, ивет, парень, лес }\end{array}$ & $99-50$ & $\begin{array}{l}271 \text { слово: добрый, один, семья, теле- } \\
\text { фон, злой, надо, папа, глупость, голос, } \\
\text { выб ор, магазин, делать, далеко, автомо- } \\
\text { биль, вечер, солнце, моя, место, дела, } \\
\text { еда, земля, чувство, добро, друзья, дети, } \\
\text { всё, он, мысли, мозг и пр. }\end{array}$ \\
\hline Пятый & $\begin{array}{c}749- \\
500\end{array}$ & $\begin{array}{l}54 \text { слова: письмо, быстро, болезнь, ра- } \\
\text { дость, страх, смерть, власть, вид, } \\
\text { много, поступок, фильм, стул, теле- } \\
\text { фон, далеко, разговор, поезд, сила, мо- } \\
\text { ре, предмет, все, война, экзамен, доро- } \\
\text { га, помошьь, умный, взгляд, счастье, } \\
\text { есть, жить, красивый, родной, стол, } \\
\text { путь, камень, бельй, птица, случай, } \\
\text { хлеб, ответ, человека, дождь, моя, } \\
\text { России, хороший, ум, большая, денег, } \\
\text { семья, нет, писатель, дерево, голос, } \\
\text { красный }\end{array}$ & 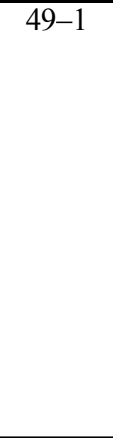 & $\begin{array}{l}49290 \text { слов; из них только } 6160 \text { имеют } \\
\text { не менее } 5 \text { связей }\end{array}$ \\
\hline Шестой & $\begin{array}{c}499- \\
250 \\
\end{array}$ & 198 слов & & The- \\
\hline Седь мой & $249-1$ & $\begin{array}{l}49369 \text { слов (97 слов выступали в каче- } \\
\text { стве реакций не менее 200 раз; } \\
609 \text { слов - не менее } 100 \text { раз; } \\
1519 \text { слов - не менее } 50 \text { раз; } 6316- \\
\text { не менее } 10 \text { раз; } 21519-\text { не менее } \\
2 \text { раз): знания, кот, лень, гордость, } \\
\text { номер, класс, длинная, яйцьо и пр. }\end{array}$ & - & $\begin{array}{l}\text { Части речи: имен существительных } \\
\text { примерно 75,6 \%; прилагательных - } \\
7,31 \% \text {; наречий - } 8,53 \text { \%; местоиме- } \\
\text { ний - 2,4 \%; глаголов - } 2,4 \%\end{array}$ \\
\hline Итого & $\begin{array}{l}7 \text { уровн } \\
1-5-\text { ac }\end{array}$ & 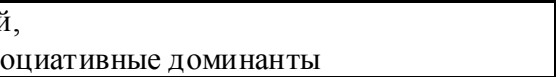 & $1-3-$ & $\begin{array}{l}\text { I, } \\
\text { оциативные доминанты }\end{array}$ \\
\hline
\end{tabular}


Таблица 2. Рейтинг ассоциативных доминант СИБАС в частотном словаре ${ }^{2}$

Table 2. SIBAS associative dominant rating in frequency dictionary

\begin{tabular}{|c|c|c|}
\hline Уровень & $\begin{array}{l}\text { Частотность, } \\
\text { ipm }\end{array}$ & Единицы \\
\hline Первый & $\begin{array}{c}35801.8- \\
11311.9\end{array}$ & $\begin{array}{l}\text { я(5): } \\
\text { входит в первую десятку самых употребительных слов }\end{array}$ \\
\hline Второй & $8354.0-2723$ & $\begin{array}{l}\text { все (35), человек (39): } \\
\text { входят в первые } 50 \text { самых частотных слов }\end{array}$ \\
\hline Третий & $\begin{array}{c}2015.7- \\
1006.1\end{array}$ & $\begin{array}{l}\text { время (52), мой (60), дело (65), жизнь (66), день (71), работа (87), большой (96): } \\
\text { входят в первую сотню самых частотных слов }\end{array}$ \\
\hline Четвертый & $874.2-471.4$ & $\begin{array}{l}\text { друг (106), нет (107), вопрос (114), да (116), дом (118), жить (126), мир (128), случай } \\
(131), \text { ребенок (137), сила }(140), \text { вид (145), всегда }(147), \text { город (156), женщина (171), } \\
\text { деньги (178), машина (187), хорошо (190), вода }(191), \text { много (196), хороший (199): } \\
\text { входят во вторую сотню самых частотных слов }\end{array}$ \\
\hline Пятый & $450.8-330.1$ & $\begin{array}{l}\text { дверь (210), власть (216), все (218), война }(219), \text { голос (221), стол (237), народ (252), } \\
\text { свет (272), путь (274), белый (290), дорога (300): } \\
\text { входят в третью сотню самых частотных слов }\end{array}$ \\
\hline Шестой & $324.9-221.6$ & $\begin{array}{l}\text { язык (306), любовь (307), взгляд (308), письмо (333), помощь (338), труд (357), } \\
\text { смерть (363), разговор (374), семья (378), ответ (396), быстро (412), мужсчина } \\
\text { (416), долго (417), вещь (434), красный (442), плохой (487): } \\
\text { входят в } 500 \text { самых частотных слов }\end{array}$ \\
\hline Седьмой & $213.3-107.4$ & 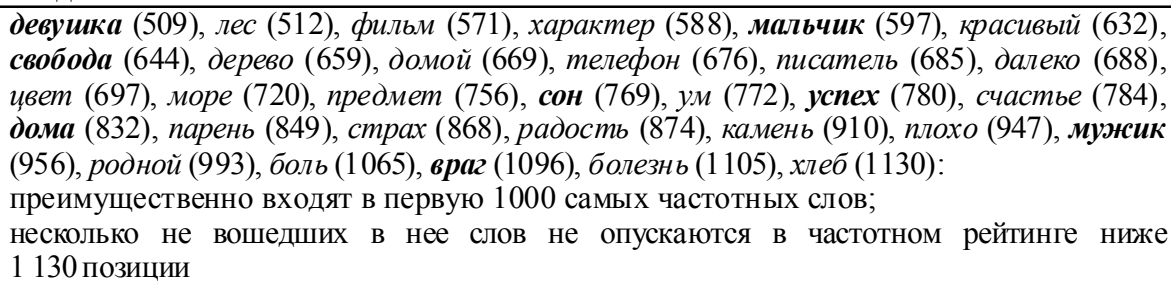 \\
\hline
\end{tabular}

Таблица 3. Параметры русской языковой личности (сравнение ассоциативных доминант СИБАС с единицами ядра языкового сознания РАС) ${ }^{3}$

Table 3. Dimensions of the Russian language personality (comparison of the SIBAS associative dominants with the core units of the Russian language consciousness from RAS)

\begin{tabular}{|c|c|c|c|c|c|}
\hline $\begin{array}{c}\text { Группы } \\
\text { доминант }\end{array}$ & PAC & СИБАС & $\begin{array}{r}\text { Группы } \\
\text { доминант }\end{array}$ & PAC & СИБАС \\
\hline Персоналии & $\begin{array}{l}\text { человек } \\
\text { друг } \\
\text { дурак } \\
\text { мужчина } \\
\text { ребенок } \\
\text { парень } \\
\text { я } \\
\text { женщина } \\
\text { мальчик } \\
\text { девушка } \\
\text { мужик } \\
\text { муж } \\
\text { он }\end{array}$ & $\begin{array}{l}\text { человек } \\
\text { друг } \\
\text { я } \\
\text { мужчина } \\
\text { ребенок } \\
\text { человека } \\
\text { люди } \\
\text { парень } \\
\text { враг } \\
\text { дурак } \\
\text { мужик } \\
\text { девушка } \\
\text { людей } \\
\text { народ } \\
\text { мальчик }\end{array}$ & Оценки & $\begin{array}{l}\text { плохо } \\
\text { хорошо } \\
\text { много } \\
\text { быстро } \\
\text { всегда } \\
\text { очень }\end{array}$ & $\begin{array}{l}\text { хорошо } \\
\text { плохо } \\
\text { много } \\
\text { всегда } \\
\text { быстро } \\
\text { долго }\end{array}$ \\
\hline \multirow[b]{2}{*}{ Реалии } & \multirow{2}{*}{$\begin{array}{l}\text { дом } \\
\text { жизнь } \\
\text { деньги } \\
\text { лес } \\
\text { день } \\
\text { любовь } \\
\text { работа } \\
\text { вода } \\
\text { радость } \\
\text { дело } \\
\text { смерть } \\
\text { стол } \\
\text { дорога } \\
\text { мир } \\
\text { дерево }\end{array}$} & \multirow{2}{*}{$\begin{array}{l}\text { жизнь } \\
\text { дом } \\
\text { деньги } \\
\text { мир } \\
\text { время } \\
\text { работа } \\
\text { любовь } \\
\text { сила } \\
\text { радость } \\
\text { смерть } \\
\text { зло } \\
\text { день } \\
\text { город } \\
\text { счастье } \\
\text { дело }\end{array}$} & Действия & $\begin{array}{l}\text { говорить } \\
\text { есть } \\
\text { жить } \\
\text { думать } \\
\text { идти } \\
\end{array}$ & $\begin{array}{l}\text { есть } \\
\text { жить }\end{array}$ \\
\hline & & & Качества & $\begin{array}{l}\text { большой } \\
\text { хороший } \\
\text { плохой } \\
\text { старый } \\
\text { умный } \\
\text { сильный } \\
\text { маленький }\end{array}$ & $\begin{array}{l}\text { большой } \\
\text { хороший } \\
\text { умный } \\
\text { плохой } \\
\text { красивый } \\
\text { большая }\end{array}$ \\
\hline
\end{tabular}


В анализе АВС СИБАС мы оперируем термином ассоциативные доминанты, выводя в обратном словаре СИБАС параметры экстенсивности и интенсивности связей. Поскольку СИБАС на текущий момент содержит данные только одного из трех необходимых для получения тезауруса этапов массового эксперимента, ассоциативные доминанты СИБАС при всем их сходстве с рядом характеристик ядра лексикона, с нашей точки зрения, могут быть истолкованы как прототип ядра, то есть рабочая модель, которой можно пользоваться до получения данных на следующих этапах эксперимента.

Методологическая роль ассоциативных доминант (ядра языкового сознания) заключается в том, что они, с одной стороны, служат материалом и средством для познания того, как именно входит конкретная вербальная этническая культура в ребенка и, с другой стороны, каким образом он сам вживляется в нее, «опрокидывая» ее системно-функциональные отношения внутрь себя и наполняя свою КММ этим содержанием. Ядро лексикона в психически актуальном смысле - значимый инструмент межъязыковых сопоставлений движения значений в актуальной диахронии (в пределах 3-4 поколений) и измерения флуктуаций системного плана в структуре овнешняемых смыслов образа мира усредненной этнокультурной языковой личности.

\section{Смысл и слово}

В отечественной психолингвистической традиции, идущей от фундаментальных положений Л.С. Выготского о единицах анализа речемыслительных процессов, всегда осознавалась нелинейность связи значений со словами, их эксплицирующими. Это выражается, в частности, в таких сентенциях А.Н. Леонтьева, как «язык не демиург значений», «значения ведут двойную жизнь», «два вида движения значений» и др. [Леонтьев, 2005, с. 100103]. Представление о функционировании значений в двух планах - психическом (как части отношений системы деятельности и сознания конкретных индивидов) и лингвистическом (общественном, культурно-историческом, надиндивидуальном, непсихическом по своей сути) - сохраняет свою актуальность и в реа- лиях сегодняшней науки. Значения психического плана предметны, так как они представляют собой, по определению А.Н. Леонтьева, «идеальные производные от предметности мира с помощью чувственной ткани» [Леонтьев, 2005, с. 100]. К этому определению психологи добавляют «биодинамическую ткань живого движения и действия» [Зинченко, 2010, c. 251], которая также «сворачивается»в структуре психически актуального значения. Оно и существует в виде личностного смысла, то есть значения для субъекта, в отношении к мотиву, как составляющая рефлексивного слоя сознания, продукт невозможного вне индивида взаимодействия его первой и второй сигнальных систем. Значения, которые изучаются лингвистикой, с точки зрения психологии надпсихологичны, надындивидуальны, абстрагированы, «отторгнуты» от реальности и начали «свое самостоятельное движение в истории языка, истории общества, культуры и науки» [Леонтьев, 2005, с. 101]. Они отражают уже ушедшую в прошлое предметную реальность. Такие значения и предьявляются ребенку в онтогенезе в виде готовых культурноспецифичных идеальных объектов, подлежащих интериоризации и осмыслению в актуальной для него предметной и социокоммуникативной реальности, то есть начинают использоваться в качестве операторов (инструментов), манипулируя которыми человек отражает мир, врастает в него, синхронно формируя его образ, насыщая его смыслами.

В работах А.И. Новикова смысл рассматривается как динамичный процесс в качестве междисциплинарного объекта в силу его составляющих: знаний о предметной реальности (предметный опыт человека, интерсубъективный по своему источнику) и жизненных установок носителей смысла по отношению к предметным реалиям мира. «Эти две составляющие смысла лежат в основе межиндивидуального общения, а потому откладываются в сознании и фиксируются как устойчивые, повторяющиеся компоненты, постоянно воспроизводимые в речи» [Новиков, 2000 , с. 34]. В отличие от знаний, с несколькими ступенями опосредованности отражающих действительность, смысл имеет более непосредственное отношение к ней. «По сути, он совершается в этой действительности, так 
как непосредственно связан с образным способом отражения конкретных объектов и ситуаций, но не самих по себе, а как бы вплетенных в множество связей и отношений, формирующихся в процессе жизнедеятельности человека и взятых в совокупности и одновременности. ...Таким образом, и смысл, и кониептуальные модели являются средством отражения действительности, но они поразному членят эту действительность (курсив наш. - И. Ш.)» [Новиков, 2000, с. 37].

Языковое значение задает диапазон оперирования предметным содержанием, создает платформу для смыслообразования; в то время как концептуальная система упорядочивает содержание с аналитической, расчленяющей действительность стороны, смысл у человеческой личности имеет доминантность, он целостен. Стало быть, существует некий разрыв между вербальным (языковым) и когнитивным (концептуальным) содержанием. Как разрешается это противоречие в психолингвистике? А.И. Новиков рассматривает общение как процесс преодоления разрыва между языковым содержанием и ментальным. Таким образом, хотя КММ и несводима к ЯММ, но разрыв между ними постоянно преодолевается в живой речевой деятельности. Аналогично проблема соотношения языка и мышления была поставлена и в работах Н.И. Жинкина, относившего ее к процессу речевой деятельности, а не к системе языка с ее уровнями. На каждом из них могут узнаваться культурно-исторически сформировавшиеся значения, но порожденный на фоне оперирования ими смысл понимается в живом ситуативно-коммуникативном процессе речемыслительной деятельности. Исследуя устройство словесных раздражителей, Н.И. Жинкин ввел в оборот психолингвистики термин универсальный предметный код (далее - УПК) для универсального языка внутренней речи человека, с которого возможны переводы на все другие языки [Жинкин, 1964, с. 35-36]. Главную мысль автора, видимо, следует понимать так: УПК, не имеющий материальных признаков слов естественного языка в виде последовательности знаков, вырастает из образов предметной реальности и человеческой интенциональности по отношению к этим реалиям.
Примечательно, что фундаментальные положения о соотношении КММ и ЯММ, о природе речемыслительных процессов развивались в отечественной науке задолго до появления современной когнитивной лингвистики в западной традиции изучения языка и мышления. В трудах А.Д. Кошелева, побуждающих к дискуссии по поводу разработки единой мультидисциплинарной теоретической платформы для построения адекватной современному уровню знаний теории языка, уже в когнитивных терминах развиваются базовые положения отечественной науки применительно к онтогенезу когнитивных способностей человека [Кошелев, 2017; 2019]. Автору удалось показать, каким образом в онтогенезе формируются и развиваются базовые концепты языка конкретной культуры, по сути его исследование позволяет перевести в доступный для понимания широкой аудитории формат описание тех явлений, которые открыты и названы Н.И. Жинкиным УПК. Развитие языка рассматривается А.Д. Кошелевым в связи со становлением всех других подсистем психики человека, в особенности с деятельностью. Автор выводит и обосновывает схемы развития базовых концептов (предметов и действий) у детей, постепенное наполнение ими детской КММ и ее последующее схватывание языком (ЯММ). Значение здесь описано в рамках динамической онтогенетической модели в процессе становления и развития его базисной смысловой оболочки (сферы) как основы для вербального выведения психически актуальных когнитивных процессов во внешнюю реальность. Эта модель позволяет продемонстрировать превращение значений и смыслов, их движение в онтогенезе и дальнейшее обращение по циклу «психически актуальное когнитивное $\leftrightarrow$ лингвистическое». Таким образом, несводимость КММ к ЯММ имеет онтогенетическое обоснование.

Слово, будучи каноническим носителем значений естественного языка, способно емко наполняться многообразным смысловым содержанием разного порядка. Слово можно сравнить с талантливо перевоплощающимся актером, у которого для этих целей имеется большой гардероб. Разные одежды словаактера ассоциируются у нас с разными его перевоплощениями, но для того, чтобы сыграть 
роль, решить текущую задачу смысловоплощения, актеру нужно разобраться в своем гардеробе, упорядочить его под ролевую задачу. Так и в лингвистике, многомерность слова позволяет проводить упорядочение лексики под разные задачи. Упорядочение слов по частоте использования в текстах напоминает гардероб, где все одежды разложены в таком порядке, который соответствует тому, сколько раз и по какому случаю каждый наряд уже был использован. В АВС лексические единицы предстают перед нами в богатом разнообразии смысловых одежд, не упорядоченных строгими логическими установками, а потому зачастую разношерстных и аляповатых, но подчиненных жизненной логике интенций и мотивов, системе актуальных смысловых доминант усредненной (здесь - русской) языковой личности. Таким образом, языковая модель мира в узлах АВС представлена вербальными единицами, стихийно упорядоченными в сознании в соответствии с системой отношений в их психически актуальной КММ. Сами цеепочк ассоциатов - актуальные для носителя языка операторы смыслообразования, а организованные по уровням устойчивости ассоичитивные доминанты - опорные точки базисной для актуальной диахронии концептуальной системь.

\section{Движение значений в глубинной диахронии}

Упорядочение лексики, позволяющее решать задачи глубинной диахронии при подборе материала для сравнительно-сопоставительного исследования и реконструкции, определении родства и времени расхождения сравниваемых языков и их семей, осуществляется в рамках так называемых списков М. Сводеша, предложившего выделять в словаре языка специальную (основную) часть. Первоначальные принципы выделения такой лексики были существенно пересмотрены позднее другими исследователями на основе применения целого ряда уточняющих критериев. Так, список был подвержен критической оценке по параметру устойчивости, когда выяснилось, что не все единицы списка могут быть одинаково устойчивыми в один и тот же промежуток времени. В этой связи
С.А. Старостин ввел понятие «индекс стабильности значения» [Старостин, 2007, с. 839]. Этот индекс применяется для ранжирования значений по степени их устойчивости и представляет собой отношение максимального числа языков, использующих для данного значения один и тот же корень, к общему числу языков в семье. В работах исследователей, оперирующих этим списком, указывается, что при любой разновидности методики ранжирования значений выделяется максимально стабильная часть, которая включает в себя чуть больше $20 \%$ от единиц в исходном 100-словном списке, чьи значения максимально устойчивы в трех и более семьях [Старостин, 2007, c. 839]. Список лексем, формирующийся в ходе такого упорядочения, носит название базисной лексики и противопоставляется в глоттогенетическом плане «культурной» лексике как достоверно установленное ядро незаимствованных лексем, соотносимых с наиболее элементарными понятиями, в отличие от лексем, исторически более изменчивых и часто заимствованных вместе с культурными реалиями более позднего времени слоев лексики [Старостин, 2007, с. 782]. С.А. Старостин отмечает, что в случае замены базисной лексики практически происходит смена языка в сообществе. Особая устойчивость базисных лексем позволяет заниматься более верифицируемыми процедурами выявления фонетических закономерностей при установлении и описании родства языков. Поскольку устойчивость значений зависит от целого ряда факторов, к списку слов для лексикостатистических исследований лингвистам приходится применять разные уточняющие критерии, связанные преимущественно с синонимическими отношениями в изучаемом языке: регистровая немаркированность отобранных единиц, отсутствие у них идиоматической связанности, исключение супплетивов, антропоцентричность смыслов, подбор функциональных антонимов, оценка частотности квазисинонимов и др. (см., например: [Kassian et al., 2010, p. 4849]). Для нас важно, что с точки зрения смыслового содержания рассматриваемые единицы отождествляются со своими именамиархетипами, соотносимыми с архетипическим же наполнением образа мира у древних сообществ в глубинной диахронии. Этот образ кон- 
струируется из вербальных маркеров реалий, с максимальной вероятностью повторяющихся при оперировании смыслами на уровне праязыков семей и даже макросемей. Слово предстает перед нами в своем исходном, элементарном, конкретно-предметном первобытном одеянии (своего рода «набедренной повязке»), лишенным смыслового богатства разнообразных закрепленных в сознании современных поколений дискурсивно-контекстуальных коннотаций. Для дальнейшего уточнения таких реалий и поиска корректных межъязыковых лексических эквивалентов для списка М. Сводеша исследователи оперируют уточняющими семантико-синтаксическими контекстами. Например, для лексемы язык дается уточнение, какой именно смысл вкладывается в данное слово: «часть тела, не 'речь'», и приводятся соответствующие семантико-синтаксические контексты: Он показал ему язык; Когда он упал, он прикусил язык. Ему больно [Kassian et al., 2010, p. 81]. Культурно редуцированное для решения лексикостатистических задач значение слова базисно с точки зрения своего исходного архетипа, материально-предметного смысла, способного устойчиво воспроизводиться на больших макростатистически обозримых диахронических глубинах при параллельной реконструкции на основе комплексных данных от разных наук о человеке исходного образа мира обитателей древней прародины народов языковой семьи (макросемьи).

Естественно, что столь жестким критериям отбора соответствуют далеко не все частотные во всей своей смысловой наполненности в современном языке и тем более актуально-активные в ассоциативно-вербальной сети единицы. Из нашего списка ассоциативных доминант только несколько единиц входят в упорядоченный по устойчивости значений список базисной в глоттохронологии лексики для русского языка ${ }^{4}$ :

Язык $(0,93) ; я(0,71) ;$ красный $(0,47) ;$ вода $(0,37)$; есть $(0,36)$; дождь $(0,34) ;$ мужчина $(0,34)$; белый $(0,32) ;$ человек $(0,30) ;$ дорога $(0,28) ;$ птица $(0,28)$; камень $(0,27) ;$ дерево $(0,24) ;$ много $(0,19) ;$ большой $(0,15) ;$ хороший $(0,13)$.

Удельный вес архетипического значения в современных употреблениях этих слов не все- гда очевиден. Так, в ассоциативном поле $\boldsymbol{Я з ы л ~}$ (обратный ассоциативный словарь - СИБАС) наблюдаем следующие показатели активации связей слов-стимулов со значением «часть тела», с физическими качествами и исходной функцией: рот 37, показать 24, губа 7, жест 3 , попробовать 3, большой, гибкий, кисльй, короткий, соль, сосать. Всего - 80 реакций словом язык. Это составляет $6,75 \%$ от их общего количества (1 184), полученного на 11 разных стимулов, $(11,8 \%$ от их общего количества 93). Даже и в этом скудном на фоне общих данных наборе связей есть двусмысленность: при их развертывании в контексты может активироваться как архетипическое значение «часть тела», так и иные значения этого слова: «речь», «язык в качестве пищевого продукта». Это показывает, насколько далеко ушло современное слово в своем смысловом репертуаре от архетипа и насколько трудно оперировать содержательным материалом при анализе движения значений в глубинной диахронии.

\section{Генеалогическое и логическое:}

\section{интегративные модели протокультуры}

Упорядочение лексики на больших глубинах времени имеет особое методологическое значение для решения конкретных задач сравнительно-сопоставительных исследований лингвистического материала. Вместе с тем глубинная компаративистика, как считают работающие в этой сфере ученые, - одна из немногих наук о доисторическом человеке, его языковых возможностях в дописьменный период [Starostin, 1999, p. 61], поэтому еe междисциплинарное значение измеряется вкладом в человековедение на стыке разных дисциплин, дающих нам представление об антропогенезе и этногенезе. Видимо, с лексикостатистической точки зрения можно вести речь о базисной лексике как генетическом (генеалогическом) ядре, отражающем глубинно диахроническую доминанту вербальной культуры носителей языка (группы языков, семьи, макросемьи). Как соотносятся такие блоки лексики языка с моделью мира далеких прародичей человека? Это вопрос о применимости и объеме лексики, релевантной для реконструкции и анализа при опреде- 
ленных условиях не только разноуровневой праязыковой субстанции, но и смысловых реалий протокультуры. Индоевропейская семья, которая включает в себя 97 языков, довольно хорошо изученных этимологически, рассматривается в глоттохронологии как семья среднего хронологического уровня [Старостин, 2007 , с. 834], что позволяет получить данные о смысловой сфере протоиндоевропейской культуры с довольно высокой степенью достоверности. Т.В. Гамкрелидзе и Вяч.Вс. Иванов создали прецедент реконструкции семантического словаря индоевропейского праязыка и протокультуры на основе метода, который они назвали «методом лингвистической палеонтологии культуры» [Гамкрелидзе, Иванов, 1984, с. 834]. В его основе лежит формально-семантическая реконструкция с опорой на логический анализ в рамках подхода по типу «сильной семантики» ${ }^{5}$. Авторы рассматривают базисную лексику в контексте мифологической и ритуальной интенциональности, то есть в связи с мотивами ритуальномифологических практик, в которых участвуют денотаты этих лексем. Установление и сравнительный анализ мифологических и ритуальных мотивов может проходить и без участия конкретных слов, такой анализ в комплексе с установлением вербально-семантических архетипов мифологем и ритуалов позволяет вести речь не только о сугубо материальном вещном мире, но и о некой общей картине духовного мира и представлений, фрагментов системы воззрений на мир древних индоевропейцев [Гамкрелидзе, Иванов, 1984, с. 460491]. Лексика упорядочивается при решении таких задач по определенным семантическим группам (полям), соотносимым с элементами и группами элементов логического порядка, зоологической и социальной иерархии (классификации) фрагментов внешнего мира. При этом авторы подчеркивают принципиально не метаязыковой характер полученной таксономии элементов, а ее принадлежность смысловому полю системы воззрений на мир [Гамкрелидзе, Иванов, 1984, с. 491], то есть, по сути, фрагментам архаической КМM. В ней человек принадлежит миру живого, куда также входят боги и животные. Люди и домашние животные объединены в субкатегорию недиких существ. Будучи суще- ствами говорящими, разумными и двуногими, люди противопоставлены по этим признакам неговорящим неразумным четвероногим (животным). В качестве смертных и земных существ они противопоставлены бессметным и небесным богам, а будучи свободными по отношению к животным, они несвободны по отношению к богам. Весь индоевропейский этимологический словарь разбит на рубрики, связанные с реалиями внешнего мира: животный, растительный мир, явления географической среды, реалии хозяйственной деятельности, социальной организации, экономики, системы родства, духовной сферы, мифологической модели мира и пр. Таким образом, протокультура предстает перед читателем в интегрированном виде как система организующих ее основных фрагментов модели мира, что позволило авторам на фоне соотнесения данных лексико-семантической реконструкции с другим культурно-историческим, этнологическим и археологическим материалом обосновать свою гипотезу о доисторической прародине индоевропейцев. По всей видимости, базисная лексика в рамках такого подхода упорядочивается и отбирается на вероятностной этимологической основе с учетом репрезентативности рассматриваемых единиц по отношению к протокультурным реалиям, при условии сверки лингвистических данных с содержательной фактической информацией из других междисциплинарных источников.

\section{Ахроничное упорядочение лексики \\ на логической основе}

Опосредованное техническими средствами взаимодействие современных людей обнажает противоречие между машинными алгоритмами оперирования информацией и необходимостью подготовить машину к общению с человеком на его естественном языке. Возникает потребность в построении логических моделей естественного языка, его логических начал и формальной семантики, переводе языковых единиц разного типа и уровня сложности на языки логики, имеющие свои уровни представления информации разного порядка. Здесь обнаруживается глубокое несоответствие между формальной логикой и обыденным языком, множество трудно- 
стей, возникающих на стыке логических моделей концептуальной сети, где главным оператором и элементом комбинирования смыслов является понятие, и сети связей и отношений языковых единиц, где операторами и элементами комбинирования выступают лингвистические значения. В этой сфере также создаются и востребованы динамические модели развертывания семантики, работающие, например, при интерпретации дискурса с динамикой отношений между операторами смысла, основанные на идее об изменении интерпретации в процессе развертывания фразы или фрагмента диалога за счет изменения объема доступной информации [Андреев, Митрофанова, Соколов, 2014, с. 59]. Оценивая попытки логико-философского подхода «исследовать смысл на субстанциональном уровне» при его соотнесении с психическими процессами у человека, А.И. Новиков определяет важнейший интегрирующий признак смысла как принцип доминантности [Новиков, 2007, c. 53] . Однако остается неясным, откуда берется доминантность? Она экстралингвистична по своей природе и задается языковой личностью с ее интенциональностью. Несомненно, она соотносится с рядом выводимых на логической основе категорий психолингвистики текста, но проявляет себя прежде всего в том, как именно оперирует лингвистическими значениями конкретная языковая личность. Например, объясняя с помощью доминантности такое фундаментальное свойство текста, как его целостность, А.И. Новиков отмечает, что при порождении текста доминантность «обеспечивается единством замысла, а при восприятии и понимании - целостностью образа содержания текста» [Новиков, 2007, c. 223], то есть так называемым «встречным текстом», «встречной проекцией сознания на текст в виде определенных ментальных структур, в частности системы связей и отношений» [Новиков, 2007, с. 21], формирующейся у читателя под воздействием его собственного коммуникативно-когнитивного опыта в ответ на исходную авторскую проекцию смысла текста. Поскольку встречная проекция в значительной степени зависит от субъекта восприятия, его интенций и доминантных установок, попытки свести это явление к общеконцептуальным и тем более сугубо формально-логическим ка- тегориям не дадут нам модели, исчерпывающей глубину процесса. Таким образом, субстанциональная ориентация на оценку объема доступной информации с точки зрения психолингвистики текста оказывается несамодостаточной.

Логика как способ получения и обработки информации о мире, образе мира человека и мышлении нуждается в онтологии сущностей, представляя их в виде логических, обобщенных форм познания мира (понятий), а также в установлении связей и отношений между ними. Характер и природа абстрактного мышления человека приводят его к построению иерархических уровневых и сетевых моделей на формально-логических основаниях. Установка на исследование логических начал в естественном языке заставляет рассматривать значение как репрезентацию логических форм, связей и отношений и привлекать слово постольку, поскольку оно является лексикализатором соответствующего концептуального содержания. Упорядоченные на логической основе концептуальныелингвистические ресурсы называют онтологиями и тезаурусами, понятийными словарями. Такие словари, как правило, дают толкования гипо-гиперонимических (родовидовых), меронимических (часть-целое), синонимических, антонимических, частично ассоциативных отношений (ср.: RuThes; RuWordNet; ruTenTen; POCC, а также [Баранов, 2014] и обзор в: [Лукашевич, 2011, с. 28-38]). В построенной на логических основаниях сети имеются гнездовые (опорные) понятия, которые в свою очередь используются для образования других понятий и рассматриваются авторами словарей как лексический минимум, «полигон при изучении русского языка и классификации понятий» [Баранов, 2014]. Работающие над созданием таких ресурсов специалисты сталкиваются с типичным явлением, когда, с одной стороны, не все представленные в концептуальной сети понятия лексикализованы в конкретном естественном языке, с другой стороны, существует множество различных неподдающихся формализации отношений (в особенности ассоциативных) между имеющимися в этом языке вербальными единицами. Фактическая информация об объеме и качественном составе концептуальных ресурсов сама по себе свидетельствует о глубин- 
ном несовпадении вербального и концептуального начал. Например, объем тезауруса РуТез составляет 158 тыс. слов и выражений, уложенных в сеть 55 тыс. понятий, между которыми вручную установлено более 210 тыс. отношений (RuThes). Те понятийные сущности, которые логикой генерализации могут относиться к какому-то одному уровню (ярусу), по вербальной «логике» могут воплощаться вхождением одной и той же единицы на разные ярусы и уровни логический сети. Таким образом, в процедуре формально-логического упорядочения лексикона естественных языков возникает не только проблема собственно выразимости явлений естественного языка средствами логики, но и проблема идентификации и взаимодействия различных носителей и компонентов лингвистических значений, подлежащих формализации: лексических и грамматических, лексико-семантических вариантов лексем, контекстуальных приращений смыслов в связи с глубинной и поверхностной валентностями языковых единиц, смысловых перевоплощений при переходе с одного языкового уровня представления семантики к другому и мн. др. Вопросы ограничений, селекции и кластеризации разных содержательных компонентов при порождении смысла составляют отдельную проблему. Это видно на примере реализованного Дж. Пустейовским в 1990-е гг. проекта генеративного лексикона, упоминаемого в ряде источников при обсуждении общетеоретических вопросов создания разных систем автоматической обработки текста [Андреев, Митрофанова, Соколов, 2014; Сокирко, 2003]. Как «логическая альтернатива классической лексической семантике» в смысле адаптации к задачам автоматической обработки текста и динамическая модель, основанная на дистрибутивных и композиционных свойствах лексического значения, генеративный лексикон противопоставляется жестким алгоритмам описания значений. Термин «генеративность» ассоциирует модель с гибким порождением новых смыслов в виде формализованных многоярусных структурных образцов, способных показывать механизмы функционирования многозначных слов в разнородных текстах. Критические отзывы о применении такой модели обусловлены отсутствием в ней ограни- чений на порождение смыслов и, как следствие, возможностью содержательной интерпретации фраз, неприемлемых в конкретных естественных языках [Андреев, Митрофанова, Соколов, 2014, с. 78] (развернутый критический анализ дается в: [Сокирко, 2003]). Наибольшими возможностями вычисления семантических связей между понятиями обладают, как нам думается, векторные дистрибутивные модели извлечения семантических отношений между словами и иными сущностями из текстов. Они заслуживают особого рассмотрения вне рамок данной статьи именно в связи с возможностью вычисления дистрибутивных векторов слов (о проекте см.: RusVectōrēs, а также: [Kutuzov, Kuzmenko, 2017]).

Концептуальные словари, формальные онтологии и тезаурусы создаются как ресурсы, которые могут быть востребованы в компьютерных системах для автоматической обработки текста в разных целях: информационно-поисковых, переводческих и др. Все они имеют общую для этих систем проблемную специфику, которая, с нашей точки зрения, вызвана несводимостью КММ к ЯММ, а также невозможностью решить задачу балансировки КММ и ЯММ наличными формальнологическими средствами. Отбор и упорядочение лексики проводится в них с привлечением лингвистических словарей и больших корпусов текстов, включая текстовые сетевые ресурсы Интернет, с широким использованием частотной статистики. Как исходные текстовые ресурсы, так и создаваемые на их основе формально-логически упорядоченные лексиконы (часто многоярусные сетевые модели) представляют собой отчужденный от конкретной языковой личности продукт ее речевой деятельности. Установление связей и отношений между единицами здесь вторично по отношению к живой речевой деятельности, оно опосредовано исходными параметрами текстов и задачами тех сфер деятельности, которые обслуживаются создаваемыми для них компьютерными ресурсами, а также потенциалом применимости технологий и методов формализации семантики к реалиям естественного языка. При теоретической разработке вопросов формализации связей и отношений концептуальной сети с соответству- 
ющими вербальными коррелятами ученые вынуждены оперировать материалом лингвистических значений лексических единиц (с их текстовыми репрезентациями), предлагая их в качестве лексификаторов логико-понятийных феноменов. Даже динамические модели этого типа представляют движение значений в отчужденной от живой языковой личности схематично генерализованной форме. В отличие от схемы движения значений, у живой языковой личности при содержательном наполнении образа мира в процессе смысловых перевоплощений онто- и психокогнитивного плана (лингвистическое значение $\leftrightarrow$ психологическое значение $\leftrightarrow$ лингвистическое значение) даже в самых продуктивных формально-логических подходах исчезает психологическое звено смыслообразования. Таким образом, выпадает из рассмотрения интенциональность языковой личности, а вместе с ней и доминантность смыслопорождения со всеми психически актуальными импликациями, логически и статистически непредсказуемыми селективными ограничениями на оперирование лингвистическим материалом.

Особо интересны в контексте нашего обсуждения компромиссные проекты словарей на основе НКРЯ и иных сетевых ресурсов (AC; Sensefreq), направленные на экспликацию семантики через установление взаимоотношений лексических значений слов, а также лексических и грамматических значений в контекстах. Сюда следует отнести масштабный проект активного словаря, выводящего толкования лексем для широкого пользователя с установкой на полноту описания и моделирования значения слова как статистически структурированного текстозависимого феномена. Статистическая упорядоченность толкований показывает в этом словаре не только интенсивность использования в текстах лексической единицы как таковой, но и относительную частоту активации различных ее лексико-семантических вариантов. Авторами выделяются приемы описания связей между лексемами и их вариантами через специально введенную рубрику «лексический мир ${ }^{6}$ лексемы, приводятся данные по синтаксической реализации связей, богатый иллюстративный контекстный материал. Особую значимость имеет реализуемая в активном слова- ре концепция лексикографических типов. По нашим наблюдениям, в АС при всем богатстве представления семантического багажа слов существуют те же ограничения, что и в других логически ориентированных подходах, однако характер представленности движения лингвистических значений в АС позволит, как думается, со временем по мере реализации этого проекта, с одной стороны, и расширения ассоциативно-вербальных баз данных, с другой, использовать эти два вида источников как комплементарные ресурсы при оценке изменчивости и устойчивости лингвистических значений отдельных слов, построении ассоциативного профиля ряда лексикографических типов (которые, возможно, и не будут совпадать с имеющимися в материалах АС).

Подводя итоги экскурсу в логическую сферу лексики, отметим, что богатый «гардероб» слова упорядочивается в ней по категориям и формирующим их признакам разного уровня обобщения, аналогично разным видам одежды: юбки, блузки, платья, брюки и т. п.; с рукавом, манжетами, воротником или без оных; по степени пригодности для общих и специальных случаев, по носкости, качеству ткани; и т. п. Это не столько подготовка к одному живому, актуально трогающему сознание зрителя образу, сколько общее упорядочение гардероба в соответствии с формальными, отвлеченными от личностноролевых и тесно связанных с ними социокоммуникативных установок рубриками.

\section{Выводы}

Образ мира человека как смысловая реальность исследуется междисциплинарно на концептуальных и языковых моделях разными отраслями лингвистики. В зависимости от постановки исследовательских проблем и решаемых в их поле задач разные отрасли оперируют разными вариантами упорядочения вербального материала. Лексикостатистика формирует список архетипических значений и правил их локализации в современном лексическом материале; по мере повышения хронологического уровня расширяются возможности оперирования базисным списком для субстанциональной реконструкции протоязыка и протокультуры. Онтолингвистика 
представляет базисную лексику как психокогнитивный субстрат для дальнейшего развития речемыслительной деятельности и содержательного наполнения образа мира языковой личности. Компьютерная лингвистика и формальная семантика упорядочивают лексикон на логической основе, подготавливая материал естественных языков для осуществления опосредованных машинными алгоритмами видов деятельности. Характерны для современного состояния всех упомянутых отраслей попытки построить динамические модели (почти всегда с опорой на статистическую упорядоченность) с тем, чтобы максимально полно охватить смысловую воплощенность языковых единиц или, наоборот, обеспечить точную селективность признаков при необходимости сведения смыслового содержания к определенным граням. Все подходы обнажают в той или иной мере несводимость КММ к ЯММ, противоречия между необходимостью оперировать лингвистическими значениями как объективно данной (внешней) языковой реальностью и попытками эксплицировать внутренний психически детерминированный механизм смыслопорождения. Макроуровневый анализ $\mathrm{ABC}$ дает возможность получить «копию» с внутреннего лексикона усредненной русской языковой личности, в котором КММ и ЯММ сбалансированы естественным путем, поскольку статистическая упорядоченность единиц базируется на детерминированности смысловой структуры образа мира, отражающей интенциональность русской языковой личности в виде психически актуальных и активных в актуальной диахронии ассоциативных доминант. В этом проявляется специфика подхода со стороны ассоциативной лексикографии. Каждый способ упорядочения лексики и выделения ее базисных (ядерных) компонентов имеет свою методологическую значимость. Комплементарное использование данных разных отраслей необходимо, например, при построении учебного курса междисциплинарной лингвистики, дающего широкую перспективу закономерностей, выявленных при разных ракурсах рассмотрения языка (филогенетическом и онтогенетическом, историко-этносоциокультурном и психокогнитивном). Все эти аспекты имеют единую смысловую основу - это разные грани человеко- образования, процесса, воплощающегося в образе мира языковой личности.

\section{ПРИМЕЧАНИЯ}

\begin{abstract}
${ }^{1}$ Модель строится на основе статистики обратного словаря СИБАС. В столбце 1 приведены данные о частоте реагирования словами, включенными в список ассоциативных доминант. Эти слова распределены по уровням в зависимости от частоты их актуализации в качестве слов-реакций (диапазоны частот приводятся для каждого уровня в отдельной ячейке), входящие в этот уровень единицы перечислены в порядке убывания частоты. Предельный показатель для вхождения в число ассоциативных доминант по частоте - 500 (не ниже пятого уровня). Все слова-реакции ниже этого уровня актуализации в число ассоциативных доминант не входят. В столбце 2 показаны уровни упорядочения в соответствии с количеством вербальных связей у слов-доминант. Предельный показатель для вхождения в число ассоциативных доминант по экстенсивности связей - 100 (не ниже третьего уровня). Единицы, соотносимые со списком Сводеша (генеалогическое ядро), выделены полужирным шрифтом.
\end{abstract}

2 Данные приводятся по частотному списку слов, представленному в: (Ляшевская, Шаров, 2009). Диапазоны частот для разных слоев показаны в ipm (частота встречаемости на 1 млн словоупотреблений), после каждого слова приводится его порядковый номер в частотном списке словаря, где слова упорядочены по частоте встречаемости в текстах НКРЯ. Увеличение номера сигнализирует о понижении частотного ранга слова в этом списке. В таблицу включены только те единицы из частотного списка, которые являются доминантами АВС СИБАС. Полужирным курсивом помечены единицы, доминирующие только по экстенсивности связей.

${ }^{3}$ Данные РАС приводятся по: [Уфимцева, 2017, с. 47-49]. Отмеченные в таблице 2 единицы, представляющие архетипические значения в списке М. Сводеша, входят и в параметры РЯЛ в АВС.

${ }^{4}$ Для сопоставления с ассоциативными доминантами СИБАС подборка слов из списка М. Сводеша для русского языка осуществлялась по ГЛБД. В скобках после каждого слова указаны индексы устойчивости соответствующих требованиям глоттохронологии значений этих слов для индоевропейских языков, данные приводятся по: [Старостин, 2007, c. 834]. Полужирным шрифтом выделены единицы, имеющие в СИБАС статус ассоциативных доминант только по показателю интенсивности. 
5 Здесь имеется в виду деление логических (формально-семантических) подходов к естественному языку на «сильную» и «слабую» семантику. Первая исходит из возможности применения к описанию языка тех же понятий и концепций, что и в логике, поскольку язык рассматривается в соотнесенности его категорий с действительностью, внешним миром, объективной реальностью, вторая возводит его значения не столько к действительности, сколько к сущностям, хранящимся в сознании говорящего. Подробнее о реализации таких подходов на стыке философии логического и лингвистического анализа с математикой и логикой в целях исследования логических начал естественного языка см., например, в: [Андреев, Митрофанова, Соколов, 2014, с. 4-6].

${ }^{6}$ «Это - условное название для большого класса лексических единиц, связанных с ключевой лексемой в словаре данного языка различными семантическими отношениями» [Апресян, 2014, с. 28].

\section{СПИСОК ЛИТЕРАТУРЫ}

Андреев А. В., Митрофанова О. А., Соколов К. В., 2014. Введение в формальную семантику. СПб. : СПбГУ. РИО. Филол. фак. 88 с.

Апресян Ю. Д., 2014. Об активном словаре русского языка // Активный словарь русского языка. Т. 1 / В. Ю. Апресян [и др.]; отв. ред. Ю. Д. Апресян. М. : Яз. слав. культуры. С. 5-36.

Баранов О. С., 2014. Русский тезаурус. Электронное издание. URL: http://thesaurus.wallst.ru/ (дата обращения: 19.12.2019).

Гамкрелидзе Т. В., Иванов Вяч. Вс., 1984. Индоевропейский язык и индоевропейцы. Реконструкция и историко-типологический анализ праязыка и протокультуры. В 2 ч. Ч. 2. Семантический словарь общеиндоевропейского языка и реконструкция индоевропейской протокультуры. Тбилиси : Изд-во Тбилис. ун-та. 889 с.

Жинкин Н. И., 1964. О кодовых переходах во внутренней речи // Вопросы языкознания. № 6 . C. 26-38.

Залевская А. А., 2005. Психолингвистические исследования. Слово. Текст : Избранные труды. М. : Гнозис. 543 c.

Зинченко В. П., 2010. Сознание и творческий акт. М. : Яз. слав.х культур. 592 с.

Караулов Ю. Н., 2010. Общая и русская идеография / отв. ред. С. Г. Бархударов. Изд. 2-е. М. : ЛИБРОКОМ. $360 \mathrm{c}$.

Кошелев А. Д., 2017. Очерки эволюционно-синтетической теории языка. М. : Изд. дом ЯСК. 528 с. (Разумное поведение и язык. Language and Reasoning).
Кошелев А. Д., 2019. О генезисе мышления и языка : Генезис понятий и пропозиций. Аристотель и Хомский о языке. Влияние культуры на язык. М. : Изд. дом ЯСК. 264 с. (Разумное поведение и язык. Language and Reasoning).

Леонтьев А. Н., 2005. Лекции по общей психологии. М. : Смысл ; КДУ. 511 с.

Лукашевич Н. В., 2011. Тезаурусы в задачах информационного поиска. М. : Изд-во Моск. ун-та. 396 с.

Новиков А. И., 2000. Смысл как особый способ членения мира в сознании //Языковое сознание и образ мира : сб. ст. / отв. ред. Н. В. Уфимцева. М. : Ин-т языкознания РАН. С. 33-38.

Новиков А. И., 2007. Текст и его смысловые доминанты / под ред. Н. В. Васильевой, Н. М. Нестеровой, Н. П. Пешковой. М. : Ин-т языкознания РАН. $224 \mathrm{c}$.

Сокирко А., 2003. Семантические словари в автоматической обработке текста (по материалам системы ДИАЛИНГ). URL: http://www.aot.ru/ docs/sokirko/sokirko-candid-2.html\#2-4 (дата обращения: 19.12.2019).

Старостин С. А., 2007. Труды по языкознанию. М. : Яз. слав. культур. 928 с. (Классики отечественной филологии).

Уфимцева Н. В., 2017. Этнопсихолингвистика как раздел теории речевой деятельности // Бубнова И. А., Зыкова И. В., Красных В. В., Уфимцева Н. В. (Нео)психолингвистика и (психо)лингвокультурология: новые науки о человеке говорящем : коллектив. моногр. / под ред. В. В. Красных. М. : Гнозис. С. 21-96.

Kassian A., Starostin G., Dybo A., Chernov V., 2010. The Swadesh Wordlist. An Attempt at Semantic Specification // Вопросы языкового родства. № 4. P. 46-89.

Kutuzov A., Kuzmenko E., 2017. WebVectors: A Toolkit for Building Web Interfaces for Vector Semantic Models // Analysis of Images, Social Networks and Texts. AIST 2016. Communications in Computer and Information Science / ed. by D. I. Ignatov [et al.]. Vol. 661. P. 155-161. [S. 1.] : Springer International Publishing AG 2017. DOI: 10.1007/978-3-31952920-2 15.

Starostin S. A., 1999. Methodology of Long-Range Comparison // Historical Linguistics and Lexicostatistics/ ed. by V. Shevoroshkin, P. J. Sidwell. Melbourne: [s. n.]. P. 61-66.

\section{ИСТОЧНИКИ И СЛОВАРИ}

$A C$ - Активный словарь русского языка. Т. 1 / В. Ю. Апресян [и др.]; отв. ред. Ю. Д. Апресян. М. : Яз. слав. культуры, 2014 - . Т. 1.408 с. ; Т. 2.736 с. 
ГЛБД - Глобальная лексико-статистическая база данных. 2011-2019 : [онлайн-ресурс]. М. : ВШЭ ; Санта Фе : Институт Санта Фе / под ред. Г. С. Старостина. URL: http://starling.rinet.ru/ new100/mainr.htm (дата обращения: 19.12.2019).

Ляшевская О. Н., Шаров С. А., 2009. Частотный словарь современного русского языка (на материалах Национального корпуса русского языка). М. : Азбуковник. URL: http:// dict.ruslang.ru/freq.php (дата обращения: 19.12.2019).

HКРЯ - Национальный корпус русского языка. URL: http://www.ruscorpora.ru (дата обращения: 19.12.2019).

PAC - Русский ассоциативный словарь / сост. Ю. Н. Караулов [и др.]. Т. 1-2. - М. : Астрель : ACT, 2002. URL: http://www.tesaurus.ru/dict/ dict.php (дата обращения: 19.12.2019).

POСС - Леонтьева Н. Н., 2003. Русский общесемантический словарь. URL: www.aot.ru/docs/ ross.html (дата обращения: 19.12.2019).

СИБАС - Русская региональная ассоциативная база данных. Сибирь и Дальний Восток-2008-2020 / авт.-сост. : И. В. Шапошникова, А. А. Романенко. URL : http://adictru.nsu.ru (дата обращения: 19.12.2019).

RuThes - Teзаypyc RuThes. URL: https:// www.labinform.ru/pub/ruthes/index.htm (дата обращения: 19.12.2019).

RuWordNet - Тезаурус русского языка RuWordNet. URL: http://ruwordnet.ru/ru (дата обращения: 19.12.2019).

RusVectōrēs - RusVectōrēs. URL: https:// rusvectores.org/ru/ (date of access: 19.12.2019).

ruTenTen - The Russian Web Corpus (ruTenTen). URL: https://www.sketchengine.eu/rutentenrussian-corpus/ (date of access: 19.12.2019).

Sensefreq - База частот значений слов для многозначных существительных, глаголов, прилагательных (Sense Frequencies. Based on the Active Dictionary of Russian). URL: http:// sensefreq.ruslang.ru/ (date of access: 19.12.2019).

\section{REFERENCES}

Andreev A.V., Mitrofanova O.A., Sokolov K.V., 2014. Vvedenie v formal'nuju semantiku [Introduction into Formal Semantics]. Saint Petersburg, $\mathrm{SPbGU}$. RIO. Filologicheskij fakul'tet. $88 \mathrm{p}$.

Apresjan Ju.D., 2014. Ob aktivnom slovare russkogo jazyka [About Active Dictionary of the Russian Language]. Apresjan Ju.D., ed. Aktivnyj slovar' russkogo yazyka. T. 1 [Active Dictionary of the Russian Language. Vol. 1]. Moscow, Yazyki slavyanskoy kultury Publ., pp. 5-36.
Baranov O.S., 2014. Russkij tezaurus. Elektronnoe izdanie [Russian Thesaurus. Electronic Edition]. URL: http://thesaurus.wallst.ru/ (accessed 19 December 2019).

Gamkrelidze T.V., Ivanov Vjach. Vs., 1984. Indoevropejskij jazyk i indoevropejcy. Rekonstrukcija i istoriko-tipologicheskij analiz prajazyka i protokul'tury. V $2 \mathrm{ch}$. Ch 2. Semanticheskij slovar' obshheindoevropejskogo jazyka i rekonstrukcija indoevropejskoj protokul'tury [Indo-European and the IndoEuropeans. A Reconstruction and Historical Typological Analysis of a Protolanguage and a Protoculture. In 2 Parts. Part 2. Semantic Dictionary of the Proto Indo-European Language and Reconstruction of the Indo-European Culture]. Tbilisi, Izd-vo Tbilisskogo universiteta. $889 \mathrm{p}$.

Zhinkin N.I., 1964. O kodovyh perehodah vo vnutrennej rechi [On Code Transitions in Inner Speach]. Voprosy jazykoznanija [Issues of Linguistics], no. 6, pp. 26-38.

Zalevskaja A.A., 2005. Psiholingvisticheskie issledovanija. Slovo. Tekst: Izbrannye Trudy [Psycholinguistic Research. The Word. Text: Selected Works]. Moscow, Gnozis Publ. 543 p.

Zinchenko V.P., 2010. Soznanie $i$ tvorcheskij akt [Consciousness and a Creative Act]. Moscow, Yazyki slavyanskih kultur Publ. 592 p.

Karaulov Yu.N., 2010. Obshhaja i russkaja ideografija [General and Russian Ideography]. Moscow, LIBROKOM Publ. 360 p.

Koshelev A.D., 2017. Ocherki jevoljucionnosinteticheskoj teorii jazyka [Issues on an Evolutionary Synthetic Theory of Language]. Moscow, Izdatelskiy dom YaSK. 528 p. (Razumnoe povedenie i yazyk [Language and Reasoning]).

Koshelev A.D., 2019. O genezise myshlenija i jazyka: Genezis ponjatij $i$ propozicij. Aristotel' $i$ Homskij o jazyke. Vlijanie kul 'tury na jazyk [On the Genesis of Mind and Language: Geneses of Concepts and Propositions. Aristotel and Chomsky about Language. Influence of Culture on Language]. Moscow, Izdatelskiy dom YaSK. 264 p. (Razumnoe povedenie i yazyk. Language and Reasoning).

Leontyev A.N., 2005. Lektsii po obshchey psikhologii [Lectures on General Psychology]. Moscow, Smysl Publ., KDU Publ. 511 p.

Lukashevich N.V., 2011. Tezaurusy v zadachah informacionnogo poiska [Thesauri and the Goals of Search for Information]. Moscow, Izdvo Moskovskogo universiteta. 396 p.

Novikov A.I., 2000. Smysl kak osobyj sposob chlenenija mira v soznanii [Sense as a Special 
Way of Segmentation of the World and Consciousness]. Ufimceva N.V., ed. Jazykovoe soznanie i obraz mira: sb. st. [Language Consciousness and Image of the World. Collected Articles]. Moscow, Institut yazykoznaniya RAN, pp. 33-38.

Novikov A.I., 2007. Tekst i ego smyslovye dominanty [Text and Its Semantic Dominants]. Moscow, Institut yazykoznaniya RAN. 224 p.

Sokirko A., 2003. Semanticheskie slovari v avtomaticheskoj obrabotke teksta (po materialam sistemy DIALING) [Semantic Dictionaries in the Automatic Processing of Texts (On the Materials of DIALING)]. URL: http://www.aot.ru/docs/sokirko/sokirko-candid2.html\#2-4 (accessed 19 December 2019).

Starostin S.A., 2007. Trudy po jazykoznaniju [Works on Linguistics]. MOSCOW, Yazyki slavyanskikh kultur Publ. 928 p. (Klassiki otechestvennoj filologii [Classics of the Russian Philology]).

Ufimceva N.V., 2017. Jetnopsiholingvistika kak razdel teorii rechevoj dejatel'nosti [Ethnopsycholinguistics as a Branch of the Theory of Speech Activity]. Bubnova I.A., Zykova I.V., Krasnyh V.V., Ufimceva N.V., eds. (Neo)psiholingvistika $i$ (psiho)lingvokul turologija: novye nauki o cheloveke govorjash hem: kollektiv. monogr. [(Neo)psycholinguistics and (Psycho)linguoculturology: New Sciences About Homo Loquens. Collective Monograph]. Moscow, Gnozis Publ., pp. 21-96.

Kassian A., Starostin G., Dybo A., Chernov V., 2010. The Swadesh Wordlist. An Attempt at Semantic Specification. Bопросы языкового родства [Journal of Language Relationship], no. 4, pp. $46-89$.

Kutuzov A., Kuzmenko E., 2017. WebVectors: A Toolkit for Building Web Interfaces for Vector Semantic Models. Ignatov D.I. et al., eds. Analysis of Images, Social Networks and Texts. AIST 2016. Communications in Computer and Information Science. [S. 1.], Springer International Publishing AG, 2017, vol. 661, pp. 155-161. DOI: 10.1007/ 978-3-319-52920-2 15.

Starostin S.A., 1999. Methodology of Long-Range Comparison. Historical Linguistics and Lexicostatistics. Melbourne, [s. n.], pp. 61-66.

\section{SOURCES}

Apresjan Ju.D., ed. Aktivnyj slovar' russkogo jazyka. T. 1 [Active Dictionary of the Russian Language].
Moscow, Yazyki slavyanskoy kultury Publ., 2014, vol. 1. 408 p.: vol. 2. 736 p.

Starostin G.S., ed. Global'naja leksikostatisticheskaja baza dannyh. 2011-2019: [onlain resurs] [The Global Lexicostatistical Database. 2011-2019: [online source]]. Moscow, VShE, Santa Fe, Institut Santa Fe. URL: http:// starling.rinet.ru/new100/mainr.htm (accessed 19 December 2019).

Ljashevskaja O.N., Sharov S.A., 2009. Chastotnyj slovar' sovremennogo russkogo jazyka (na materialah Nacional'nogo korpusa russkogo jazyka) [Word Frequencies in the Modern Russian Language (Based on the Russian National Corpus)]. Moscow, Azbukovnik Publ. URL: http://dict.ruslang.ru/freq.php (accessed 19 December 2019).

Nacional'nyj korpus russkogo jazyka [The Russian National Corpus]. URL: http://www.ruscorpora.ru (accessed 19 December 2019).

Karaulov Ju.N., Sorokin Ju.A., Tarasov E.F., Ufimceva N.V., Cherkasova G.A., eds. Russkij associativnyj slovar' [Russian Associative Dictionary]. Vol. 1-2. Moscow, Astrel Publ., AST Publ., 2002. URL: http://www.tesaurus.ru/dict/ dict.php (accessed 19 December 2019).

Leont'eva N.N., 2003. Russkij obshhesemanticheskij slovar [Russian General Semantics Dictionary]. URL: www.aot.ru/docs/ross.html (accessed 19 December 2019).

Shaposhnikova I.V., Romanenko A.A. Russkaja regional'naja associativnaja baza dannyh. Sibir' $i$ Dal'nij Vostok - 2008-2020 [Russian Regional Associative Database. Siberia and Far East-2008-2020]. URL: http://adictru.nsu.ru (accessed 19 December 2019).

Tezaurus RuThes [RuThes Thesaurus]. URL: https:// www.labinform.ru/pub/ruthes/index.htm (accessed 19 December 2019).

Tezaurus russkogo jazyka RuWordNet [Thesaurus of Russian Language RuWordNet.]. URL: http:// ruwordnet.ru/ru (accessed 19 December 2019).

RusVectōrēs. URL: https://rusvectores.org/ru/ (accessed 19 December 2019).

The Russian Web Corpus (ruTenTen). URL: https:// www.sketchengine.eu/rutenten-russian-corpus/ (accessed 19 December 2019).

Baza chastot znachenij slov dlja mnogoznachnyh sushhestvitel'nyh, glagolov, prilagatel'nyh [Sense Frequencies. Based on the Active Dictionary of Russian]. http://sensefreq.ruslang.ru/ (accessed 19 December 2019). 


\section{Information About the Author}

Irina V. Shaposhnikova, Doctor of Sciences (Philology), Professor, Chief Researcher, Institute of Philology of Siberian Branch of Russian Academy of Sciences, Nikolaeva St, 8, 630090 Novosibirsk, Russia, i.shaposhnickowa@yandex.ru,https://orcid.org/0000-0003-3519-1209

\section{Информация об авторе}

Ирина Владимировна Шапошникова, доктор филологических наук, профессор, главный научный сотрудник, Институт филологии Сибирского отделения РАН, ул. Николаева, 8, 630090 г. Новосибирск, Россия, i.shaposhnickowa@yandex.ru, https://orcid.org/0000-0003-3519-1209 